\title{
JITT with assessment for learning: Investigation and improvement of students understanding of kinematics concept
}

\author{
Akhmad Jufriadi ${ }^{1,}$ a $*$, Ratri Andinisari ${ }^{2, b}$ \\ ${ }^{1}$ Universitas Kanjuruhan Malang. Jalan S. Supriadi No 48, Malang 65148, Indonesia \\ ${ }^{2}$ National Central University. No. 300, Zhongda Rd., Zhongli District, Taoyuan City 32001, Taiwan \\ a akhmadjufriadi@unikama.ac.id, b ratriandini@g.ncu.edu.tw \\ * Corresponding Author.
}

Received: 21 July 2020; Revised: 10 August 2020; Accepted: 19 August 2020

\begin{abstract}
This study aims to investigate and explore students' understanding of the concept of kinematics, particularly in the concepts of acceleration, velocity, distance and displacement. This research used a mixed-method approach with embedded experimental design. The research was conducted by involving 21 students consisting of 7 men and 14 women. This research used reasoned multiple-choice questions and short interviews to determine the students' initial and final understanding. The results showed that, before the intervention was carried out, as much as $42.86 \%$ of students did not understand the concept of distance and displacement correctly, as much as $26.99 \%$ of students did not understand the concepts of instantaneous velocity and average speed, as much as $45.6 \%$ did not understand the concepts of position, velocity and acceleration and as much as $87.31 \%$ did not understand about the direction of velocity and acceleration. In addition, the results showed that the application of JITT with assessment for learning could significantly improve students' understanding of concepts, with $\mathrm{N}$-gain $=0.56$ and effect size $=$ 2.38. This study explains the difficulties and general understanding of students on the ideas of distance and displacement, and the direction of object acceleration. In addition, the integration of assessment for learning to JITT is an option in the learning process to improve understanding of Kinematics concepts.

Keywords: JITT, Assessment, Conceptual Understanding, Kinematics.
\end{abstract}

How to Cite: Jufriadi, A., \& Andinisari, R. (2020). JITT with assessment for learning: Investigation and improvement of students understanding of kinematics concept. Momentum: Physics Education Journal, 4(2), 94-101. https://doi.org/10.21067/mpej.v4i2.4669

\section{Introduction}

Understanding the concept in Physics is indeed not easy, particularly for novice students. Whereas understanding a concept may influence the understanding of other physics concepts, as many physics concepts interrelate from one concept to another. Clear interpretation of a concept may make comprehension of other concepts simpler for students, and it will help them to understand more complicated concepts. One of the most fundamental concepts in physics is the principle of kinematics, such as distance, displacement, velocity, and acceleration (Clement, 1982; Handhika et al., 2018; Pulgar et al., 2020). This concept is a core principle that needs to be acquired in order to understand Physics concepts, such as dynamics.

Physics education researchers have conducted studies, research and investigations on initial understanding and challenges experienced by the students (Lichtenberger et al., 2017; Planinic et al., 2019; Sutopo \& Waldrip, 2014), which could be used to compile a curriculum to support students understand the concepts of Physics, in particular kinematics. Knowing students' initial understanding and challenges in grasping the concept could very well enable teachers, lecturers, curricula designers to develop a strategy and measure to improve and enhance student understanding. Numerous research has shown that students have problems explaining the concepts of velocity and acceleration 
(Barniol \& Zavala, 2014; Reif \& Allen, 1992; Rosenblatt et al., 2008; Rosenblatt \& Heckler, 2011; Sutopo et al., 2012; Trowbridge \& McDermott, 1981), challenges in understanding different graphic information in Kinematics (Bollen et al., 2016; Handhika et al., 2019; Maries \& Singh, 2013; Planinic et al., 2012, 2019), challenges in understanding the concept of kinematics with different representations (Lichtenberger et al., 2017).

To overcome student's difficulty in understanding the concepts of Physics, numerous learning strategies, models, and approaches were developed along with the development of the instructional media and technology to support the learning process based on the needs of the students; one of them is problem-based learning instructional media and worksheet for Kinematics topic (Kurniawati, 2019; Muliyati et al., 2020; Sari et al., 2020). In addition, the previous research has shown that a wellprepared and well-planned instructional model allows the student to improve their comprehension about the concepts of Physics.

These days, the rapid development of technology and information influences the learning process of students. By integrating technology and information within the instructional media and model in the classroom, commonly called blended learning, it supports students to achieve the desired goal of learning objectives and target. Also, blended learning enables to create a positive learning atmosphere and allows students to communicate their ideas about a certain concept (Dziuban et al., 2018; Setiawan et al., 2019). One example of blended learning development is Just In Time Teaching (JITT) (Wati et al., 2017). Several previous research has shown that JITT instructional model improves students' understanding of the certain concept (Ayu et al., 2019), learning outcomes (Sudarma, 2015), as well as student's critical and analytical thinking (Irwandani, 2014; Wati et al., 2017). In addition, evaluating the development of students' conceptual mastery through learning assessment can help to overcome the difficulties and problems they experience during the learning process (Kusairi et al., 2019).

While most studies have been conducted on the application of the JITT, and the assessment for learning, the integration assessment for learning with the JITT seems to be very limited. As a result, JITT's learning assessment is expected to improve students' ability to understand the concepts of physics that are being learned. This is based on the impact of both the independent implementation of the learning process on student mastery of concepts (Ayu et al., 2019; Kusairi et al., 2019). With such an integration, the impact is expected to result in increased and better mastery. The objectives of this research were to determine the students' initial understanding and challenges of the kinematics concept of distance and displacement, velocity and acceleration before and after the learning process. A further objective is to determine students' mastery of concepts after the learning process is carried out using the JITT with a learning assessment.

\section{Method}

This study employed a mixed-method approach by using an embedded experiment with one phase, as shown in Figure 1 (Edmonds \& Kennedy, 2017). The quantitative data used in the analysis were the students' pre-test and post-test scores with the same test instrument. While the qualitative data used was the result of in-depth interviews during the learning process.

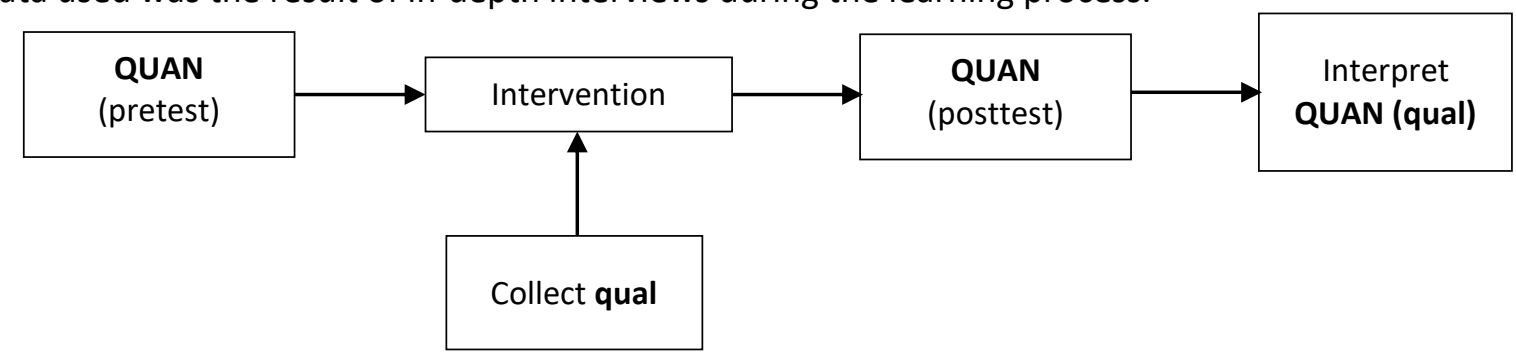

Figure 1. Mix Method Approaches: Embedded-Experiment (one-phase)

The research subjects were 21 students of the Physics Education study program in the first semester of the 2019-2020 academic year who took Basic Physics course. The research instrument 
was 12 items of reasoned multiple-choice questions, which were developed from $\mathrm{FCl}$ questions (Hestenes et al., 1992) and questions from textbooks (Serway \& Jewett, 2018). An overview of the indicators of each Kinematics test item (Serway \& Jewett, 2018), is presented in Table 1.

Table 1. Test Instrument Indicator

\begin{tabular}{lc}
\hline \multicolumn{1}{c}{ Test Indicator } & Number of Items \\
\hline Describing distance and displacement & $1,2,3$ \\
Describing instantaneous velocity and average velocity & $4,5,6$ \\
Describing position, velocity and acceleration & $7,8,9$ \\
Describing the direction of velocity and acceleration & $10,11,12$ \\
\hline
\end{tabular}

The pre-test was carried out at the beginning of the learning to find out the students' initial understanding of the concept of kinematics, and the post-test was carried out at the end of the learning. The Kinematics topics discussed are distance, displacement, position, velocity and acceleration. The learning was carried out using the JITT model, which began by giving warming-up test questions, studying and discussing the Kinematics concepts through online platform. Then, it was continued with face-to-face learning in class by discussing the topics and warming-up test questions and discussing various problem-solving. To control student understanding, an online learning for assessment was carried out. In detail, the JITT learning phase with the assessment for learning is shown in Figure 2.

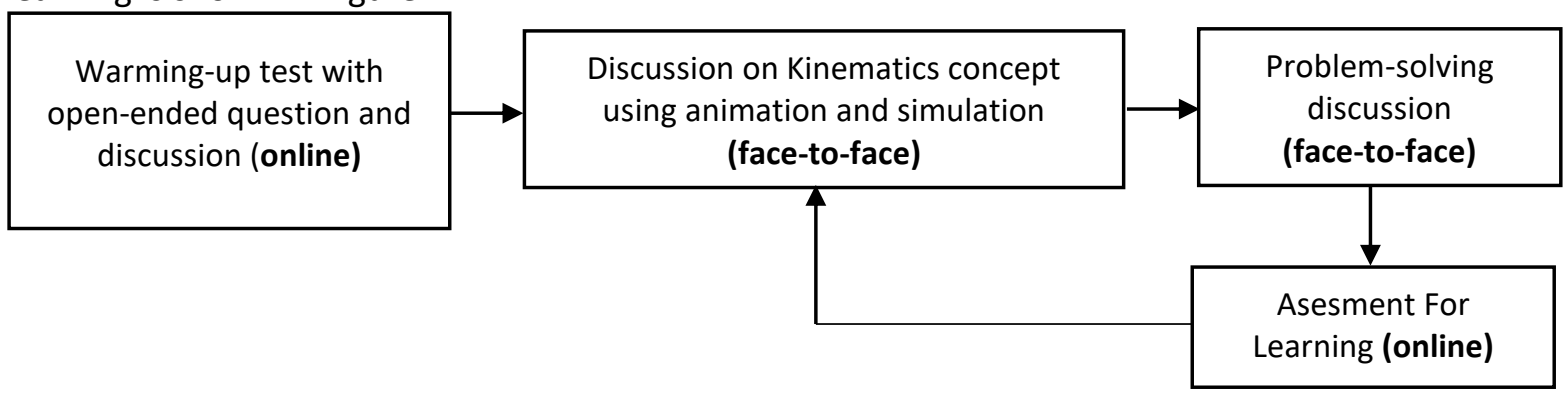

Figure 2. Process flow of JITT with assessment for learning

The data analysis was performed by calculating the normalized effect size and gain (Bao, 2006), according to the students' response on the pre-test and post-test. The data analysis was performed to determine students' conceptual understanding and improvement. Furthermore, to determine the difficulties encountered by the students, it employed qualitative data analysis based on the reasons explained within pre-test and post-test responses.

\section{Results and Discussion}

According to the students' response during the pre-test and post-test, it obtained that the students' understanding increased as presented in Table 2. It further confirms that in general, the students' conceptual mastery about Kinematics topic improved. The average score of conceptual mastery obtained by the students improved from 46.8 to 75.4 .

Table 2. Descriptive statistics of student mastery concept based on pre-test and post-test

\begin{tabular}{lll}
\hline \multicolumn{1}{c}{ Statistics } & Pre-test & Posttest \\
\hline $\mathrm{N}$ & 21 & 21 \\
Mean & 46,8 & 76,6 \\
Maximum & 66,6 & 91,6 \\
Minimum & 25 & 41,6 \\
Standard Deviation & 10,4 & 11,39 \\
\hline
\end{tabular}

To show that there is a significant difference between the pre-test and post-test scores, a paired t-test has been carried out with a significance value of 0.000 , which was less than 0.05 . This shows that there are differences in students' mastery of concepts before and after the intervention. Based on the calculated $\mathrm{N}$-gain score of $\mathbf{0 . 5 6}$, it is at a medium level score with a fairly effective 
category (Hake, 1998), and the value of Cohen's d-effect size (Ellis, 2010) was 2.38 with a very strong category (Cohen et al., 2007; Morgan et al., 2004). This shows that the intervention carried out, JITT with assessment for learning, has a strong and effective effect of changing and improving students' conceptual mastery on the topic of kinematics. These results are consistent with other studies that compare the influence of JITT with conventional models and show that the application of the JITT model to the learning process improves students' conceptual mastery (Ayu et al., 2019; Sudarma, 2015), students' creative thinking (Irwandani, 2014), and students' analytical thinking (Wati et al., 2017). In addition, the JITT application with assessment for learning supports students to build their concepts through the learning, particularly during the initial phase, which is carried out through an online platform. In this initial phase, students are able to discuss, explore to learn everything regarding the topics for the next session and try to give the best response to the test. In addition, the implementation of the assessment for learning has also provided initial information about student difficulties.

Based on the analysis and the comparison of student responses between the pre-test and post-test, it can be seen that in general students experience an increase in understanding of each sub-topic, which is shown in Table 3. Student responses to the pre-test indicate that students' initial understanding was very weak on sub-topics 1, 3 and 4. At the same time, the students' responses to the post-test showed that the students' understanding of sub-topic 4 was still very weak. This shows that students still have difficulty in mastering the concepts of kinematics.

Table 3. Students' Responses in Tests

\begin{tabular}{lll}
\hline \multicolumn{1}{c}{ Test Indicator in Each Sub-topic } & \multicolumn{2}{c}{ Correct Answer (\%) } \\
\cline { 2 - 3 } & Pre-test & Post-test \\
\hline Describing distance and displacement & 57,14 & 93,65 \\
Describing instantaneous velocity and average velocity & 73,01 & 95,23 \\
Describing position, velocity and acceleration & 44,4 & 80,95 \\
Describing the direction of velocity and acceleration & 12,69 & 36,5 \\
\hline
\end{tabular}

In the first sub-topic, especially on item 1 (see Figure 3 ), at first most students did not understand the difference between displacement and distance travelled. The percentage of students who answered correctly (d. Smaller or same) was $19 \%$. From the arguments presented by the students, it was known that the students' initial understanding was that cars always move in a straight line and do not turn. From the discussion at the initial stage and the conceptual adjustment stage, this understanding was established because on the topic of kinematics there are several sub-topics that discuss the straight motion, regular straight motion and regular changing straight motion.

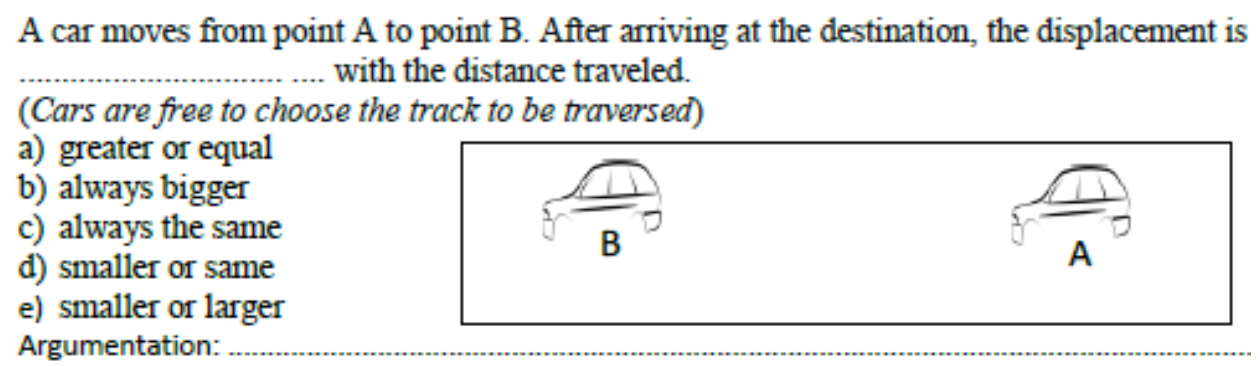

Figure 3. Item Number 1 (" $d$ " is the correct answer)

The results of the analysis of the students' initial understanding were used as a knowledge to design the intervention process (Docktor \& Mestre, 2014), especially at the concept adjustment stage. The post-test results for the first sub-topic of item 1 showed that the students' mastery of concepts, in general, had changed. Therefore the percentage of students who answered correctly was $90.47 \%$. Of the four sub-topics, it is known that the lowest understanding of the concept of students is the fourth sub-topic when explaining the direction of speed and acceleration. From the results of the pre-test and post-test, students who answered correctly only reached $12.69 \%$ and $36.5 \%$. Students experienced difficulties on item 11 and 12 (see Figure 4). 


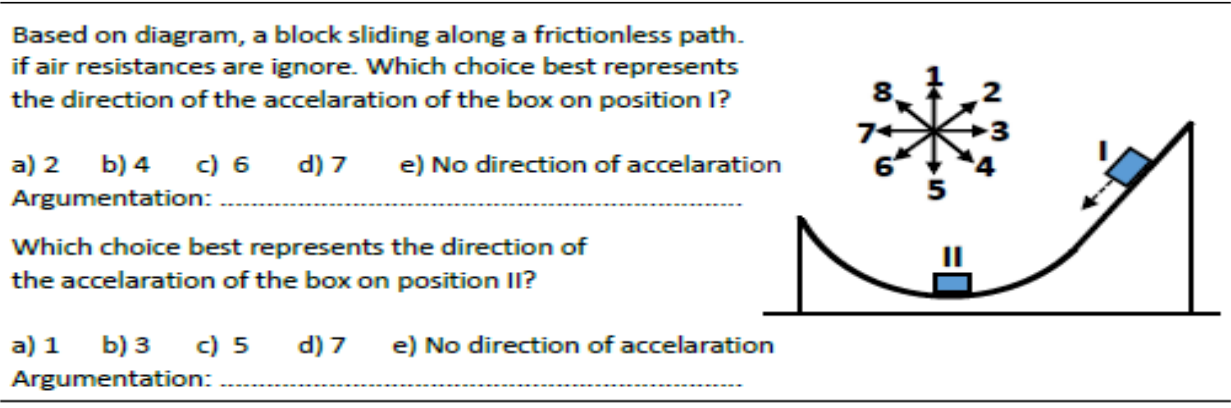

Figure 4. Item number 11 (the correct answer is c) and 12 (the correct answer is a)

In item number $11,42 \%$ of students were able to answer correctly, and the reason was that the direction of velocity is the same as the direction of acceleration. At the same time, the rest of students chose a, b, d, e (each of 14.29\%) without conveying their arguments. In question item 12, only one student (4.7\%) answered correctly, but the student did not provide an argument for the answer presented. Most of the students chose the answer $d(47.6 \%)$ and argued that at that position the box is influenced by the force of gravity thus the acceleration of the box is the same as the acceleration of gravity, which is downward. Furthermore, as much as $23.8 \%$ of students chose option e. They explained that the box at that point is stationary and has no acceleration; thus, the acceleration of the box has no direction. Then, as much as $14.3 \%$ chose option $\mathbf{c}$. They explained that the direction of the acceleration is the same as the direction of the velocity, at that position the speed of the block is towards the left (towards number 7) thus the direction of acceleration is towards the left. Then as many as $9.5 \%$ of students chose answer $\mathbf{b}$. They explained that the objects in the right position would go up. Thus there was a force acting in the opposite direction because the acceleration was in the direction of the force. Hence the direction of acceleration was also to the right (towards number 3).

General in-depth discussions and interviews were conducted during the conceptualization phase. From the analysis of student responses confirmed through in-depth interviews, it is known that in general students experience difficulties in several sub-topics, including (1) distinguishing between distance and displacement, this is due to students' understanding that moving objects are always in a straight line; (2) determining the direction of the object's acceleration (case number 12), this is due to the understanding that the object is only affected by the force of gravity or the object at that position is at rest. The difficulties and understanding of these students are also in accordance with the results of investigations and previous research which found that students have difficulty distinguishing distances and displacements, analyzing the direction of acceleration, distinguishing velocity and acceleration (Beichner, 1994; Handhika et al., 2018; Shaffer \& McDermott, 2005). From the analysis of students' understanding and conceptual mastery, it is recommended to explain the concepts of distance and displacement, position, instantaneous velocity, average velocity, and acceleration must be accompanied by graphics and visualizations of moving objects.

\section{Conclusion}

When learning the concept of kinematics, the students experience some difficulties, especially in understanding the differences between distance and displacement, velocity and acceleration, and the direction of acceleration of a moving object. Students' understanding and conceptual mastery changed and increased after the intervention was carried out through the application of JITT with assessment for learning. The application of JITT with assessment for learning has a strong influence on Kinematic conceptual mastery. Therefore, JITT with assessment for learning can be applied to improve students' conceptual mastery about kinematics.

\section{References}

Ayu, H. D., Syagita, U., \& Jufriadi, A. (2019). The effect of just in time teaching (JITT) learning model on the concept mastery of students learning motivation. Jurnal Pengajaran MIPA, 24(1). 
https://doi.org/10.18269/jpmipa.v24i1.17052

Bao, L. (2006). Theoretical comparisons of average normalized gain calculations. American Journal of Physics, 74(10), 917-922. https://doi.org/10.1119/1.2213632

Barniol, P., \& Zavala, G. (2014). Force, velocity, and work: The effects of different contexts on students' understanding of vector concepts using isomorphic problems. Physical Review Special Topics - Physics Education Research, 10(2), 020115. https://doi.org/10.1103/PhysRevSTPER.10.020115

Beichner, R. J. (1994). Testing student interpretation of kinematics graphs. American Journal of Physics, 62(8), 750-762. https://doi.org/10.1119/1.17449

Bollen, L., De Cock, M., Zuza, K., Guisasola, J., \& van Kampen, P. (2016). Generalizing a categorization of students' interpretations of linear kinematics graphs. Physical Review Physics Education Research, 12(1), 010108. https://doi.org/10.1103/PhysRevPhysEducRes.12.010108

Clement, J. (1982). Students' preconceptions in introductory mechanics. American Journal of Physics, 50(1), 66-71. https://doi.org/10.1119/1.12989

Cohen, L., Manion, L., \& Morrison, K. (2007). Research methods in education (6th ed.). Routledge.

Docktor, J. L., \& Mestre, J. P. (2014). Synthesis of discipline-based education research in physics. Physical Review Special Topics - Physics Education Research, 10(2), 020119. https://doi.org/10.1103/PhysRevSTPER.10.020119

Dziuban, C., Graham, C. R., Moskal, P. D., Norberg, A., \& Sicilia, N. (2018). Blended learning: the new normal and emerging technologies. International Journal of Educational Technology in Higher Education, 15(1), 3. https://doi.org/10.1186/s41239-017-0087-5

Ellis, P. D. (2010). The essential guide to effect sizes: statistical power, meta-analysis, and the interpretation of research results. Cambridge University Press.

Hake, R. R. (1998). Interactive-engagement versus traditional methods: A six-thousand-student survey of mechanics test data for introductory physics courses. American Journal of Physics, 66(1), 64-74. https://doi.org/10.1119/1.18809

Handhika, J., Cari, C., Suparmi, A., Sunarno, W., \& Purwandari, P. (2018). Development of diagnostic test instruments to reveal level student conception in kinematic and dynamics. Journal of Physics: Conference Series, 983(1), 012025. https://doi.org/10.1088/1742-6596/983/1/012025

Handhika, J., Istiantara, D. T., \& Astuti, S. W. (2019). Using graphical presentation to reveals the student's conception of kinematics. Journal of Physics: Conference Series, 1321, 032064. https://doi.org/10.1088/1742-6596/1321/3/032064

Hestenes, D., Wells, M., \& Swackhamer, G. (1992). Force concept inventory. The Physics Teacher, 30(3), 141-158. https://doi.org/10.1119/1.2343497

Irwandani, I. (2014). Model pembelajaran just in time teaching (JITT) berbantuan website pada topik listrik arus bolak-balik untuk meningkatkan keterampilan berpikir kreatif siswa SMA. Jurnal Ilmiah Pendidikan Fisika Al-Biruni, 3(2). https://doi.org/10.24042/jpifalbiruni.v3i2.72

Kurniawati, I. D. (2019). Development of problem-based kinematics teaching material to improve students' critical thinking skills. JIPF (Jurnal IImu Pendidikan Fisika), 4(1), 21. https://doi.org/10.26737/jipf.v4i1.910

Kusairi, S., Noviandari, L., Parno, P., \& Pratiwi, H. Y. (2019). Analysis of students' understanding of motion in straight line concepts: Modeling instruction with formative e-assessment. International Journal of Instruction, 12(4), 353-364. https://doi.org/10.29333/iji.2019.12423a

Lichtenberger, A., Wagner, C., Hofer, S. I., Stern, E., \& Vaterlaus, A. (2017). Validation and structural analysis of the kinematics concept test. Physical Review Physics Education Research, 13(1), 010115. https://doi.org/10.1103/PhysRevPhysEducRes.13.010115

Maries, A., \& Singh, C. (2013). Exploring one aspect of pedagogical content knowledge of teaching assistants using the test of understanding graphs in kinematics. Physical Review Special Topics - 
Physics Education Research, 9(2), 020120. https://doi.org/10.1103/PhysRevSTPER.9.020120

Morgan, G. A., Leech, N. L., Gloeckner, G. W., \& Barret, K. C. (2004). SPSS for introductory statistics: Use and interpretation. Lawrence Erlbaum Associates, Inc.

Muliyati, D., Septiningrum, A. D., Ambarwulan, D., \& Astra, I. M. (2020). The development of guided inquiry student worksheet using tracker video analysis for kinematics motion topics. Journal of Physics: Conference Series, 1491(1), 012062. https://doi.org/10.1088/17426596/1491/1/012062

Planinic, M., Milin-Sipus, Z., Katic, H., Susac, A., \& Ivanjek, L. (2012). Comparison of student understanding of line graph slope in physics and mathematics. International Journal of Science and Mathematics Education, 10(6), 1393-1414. https://doi.org/10.1007/s10763-012-9344-1

Planinic, M., Susac, A., Ivanjek, L., \& Milin Šipuš, Ž. (2019). Comparing student understanding of graphs in physics and mathematics. In Mathematics in Physics Education (pp. 233-246). Springer International Publishing. https://doi.org/10.1007/978-3-030-04627-9_10

Pulgar, J., Spina, A., Ríos, C., \& Harlow, D. B. (2020). Contextual details, cognitive demand and kinematic concepts: exploring concepts and characteristics of student-generated problems in a university physics course. 2019 Physics Education Research Conference Proceedings, January. https://doi.org/10.1119/perc.2019.pr.Pulgar

Reif, F., \& Allen, S. (1992). Cognition for interpreting scientific concepts: A study of acceleration. Cognition and Instruction, 9(1), 1-44. https://doi.org/10.1207/s1532690xci0901

Rosenblatt, R., \& Heckler, A. F. (2011). Systematic study of student understanding of the relationships between the directions of force, velocity, and acceleration in one dimension. Physical Review Special Topics - Physics Education Research, 7(2), 020112. https://doi.org/10.1103/PhysRevSTPER.7.020112

Rosenblatt, R., Sayre, E. C., Heckler, A. F., Henderson, C., Sabella, M., \& Hsu, L. (2008). Toward a comprehensive picture of student understanding of force, velocity, and acceleration. AIP Conference Proceedings, 1064(C), 183-186. https://doi.org/10.1063/1.3021249

Sari, R. R., Abdurrahman, \& Herlina, K. (2020). Development and validation of students' worksheet based on guided-inquiry to improve students' scientific literacy skills of junior high school on straight motion concept. Journal of Physics: Conference Series, 1467(1), 012073. https://doi.org/10.1088/1742-6596/1467/1/012073

Serway, R. A., \& Jewett, J. W. (2018). Physics for scientists and engineers with modern physics. Cengage learning.

Setiawan, R., Mardapi, D., Pratama, A., \& Ramadan, S. (2019). Efektivitas blended learning dalam inovasi pendidikan era industri 4.0 pada mata kuliah teori tes klasik. Jurnal Inovasi Teknologi Pendidikan. https://doi.org/10.21831/jitp.v6i2.27259

Shaffer, P. S., \& McDermott, L. C. (2005). A research-based approach to improving student understanding of the vector nature of kinematical concepts. American Journal of Physics, 73(10), 921-931. https://doi.org/10.1119/1.2000976

Sudarma, T. F. (2015). Pengaruh metode just-in time teaching terhadap hasil belajar fisika. Jurnal Ikatan Alumni Fisika, 1(1), 38. https://doi.org/10.24114/jiaf.v1i1.2688

Sutopo, Liliasari, Waldrib, B., \& Rusdiana, D. (2012). Impact of representational approach on the improvement of students' understanding of acceleration. Jurnal Pendidikan Fisika Indonesia, 8(2), 161-173. https://doi.org/10.15294/jpfi.v8i2.2156

Sutopo, S., \& Waldrip, B. (2014). Impact of a representational approach on students' reasoning and conceptual understanding in learning mechanics. International Journal of Science and Mathematics Education, 12(4), 741-765. https://doi.org/10.1007/s10763-013-9431-y

Trowbridge, D. E., \& McDermott, L. C. (1981). Investigation of student understanding of the concept of acceleration in one dimension. American Journal of Physics, 49(3), 242-253. 
Momentum: Physics Education Journal, 4 (2), 2020, 101

Akhmad Jufriadi, Ratri Andinisari

https://doi.org/10.1119/1.12525

Wati, I. K., Maridi Maridi, \& Ramli, M. (2017). Pengembangan model pembelajaran just in time teaching (JITT) berbasis pendekatan saintifik pada materi jamur untuk meningkatkan kemampuan berpikir analitis siswa kelas X SMA. Jurnal Inkuiri, 6(1), 121-140. https://doi.org/10.20961/inkuiri.v6i1.17276 